\title{
O QUE VEM A SER ECOLINGUÍSTICA, AFINAL?
}

\author{
(What is ecolinguistics, after all?)
}

\author{
Hildo Honório do Couto ${ }^{1}$ \\ (Universidade de Brasília - UnB)
}

\begin{abstract}
The main purpose of this article is to give an overview of what is done at the University of Brasilia in terms of ecolinguistics. After refuting some misunderstandings related to it, the papers presented during the I Brazilian Meeting of Ecolinguistics (I EBE) are briefly presented. This is followed by a presentation of the main areas of investigation in the domain of ecolinguistics, showing that there are several ones. Then we have an extensive presentation of 'ecosystemic linguistics', the specific type of ecolinguistics practiced by the members of the Brasilia School of Ecolinguistics. It does not apply ecological concepts to language phenomena as metaphors. On the contrary, it sees its object of study as a part of general ecology, i.e., ecological linguistics, or ecolinguistics for short. The 'ecology of communicactive interaction' is an important component of this view. It is the nucleus of language, from which everything emerges. It also includes 'communion', first suggested by Malinowski as 'phatic communion'. In order for there to be a smooth process of 'communicative interaction' there must be a local 'microcommunion', whereas for there to be a 'system' there must first be a 'system communion'. Last but not least, it is shown that ecolinguistics is not simply a new theory in the market, but a new way of looking at language, a holistic one. Keeping it in mind, it is possible to investigate any kind of language phenomena, including 'systemic' ones.
\end{abstract}

Key words: ecoliguistics, ecosystem linguistics, communicative interaction, communion

1. Mestre pela USP (1973), Doutor pela Universidade de Colônia Alemanha (1978), Professor Titular Aposendado da UnB, onde ainda ministra aulas na PósGraduação e orienta dissertações de mestrado e teses de doutorado. Principais áreas de atuação: Fonologia, Contato de Línguas, Ecolinguística. 


\section{RESUMO}

Um dos objetivos deste artigo é apresentar uma visão de conjunto do que se vem fazendo na Universidade de Brasília em termos de ecolinguística. Após refutar alguns mal-entendidos de que ela tem sido vítima, apresenta o que foi discutido durante o I Encontro Brasileiro de Ecolinguística (I $E B E)$, seguido de um breve conspecto das principais áreas de investigação ecolinguística, mostrando que elas já são muitas. A seguir, vem uma detalhada apresentação da 'linguística ecossistêmica', vertente da ecolinguística praticada pela Escola Ecolinguística de Brasília. Ela não aplica conceitos ecológicos nos estudo dos fenômenos da linguagem como metáforas. Pelo contrário, considera a ecolinguística como um ramo da ecologia geral, a ecologia linguística, mais comumente chamada de 'ecolinguística'. Um dos componentes centrais dessa visão da linguagem é a 'ecologia da interação comunicativa'. É a partir dos 'atos de interação' que a compõem que emerge tudo na linguagem. Inclui o conceito de 'comunhão', derivado da 'comunhão fática' de Malinowski. Trata-se de uma espécie de solidariedade, de predisposição para a comunicação, que mantém a coesão tanto dos atores de um ato de interação comunicativa quanto do sistema como um todo. Finalmente, mostra que a ecolinguística não é apenas mais uma teoria linguística no mercado. Ela é um novo modo de se encararem os fenômenos da linguagem, holística, ecológica. Mantendo isso em mente, pode-se estudar qualquer fenômeno linguístico, inclusive gramaticais, ecolinguisticamente.

Palavras-chave: ecolinguística, linguística ecossistêmica, interação comunicativa, comunhão

\section{Introdução}

Se o próprio conceito de 'linguística' é estranho para o leigo, estranheza maior ele manifesta quando ouve a palavra 'ecolinguística'. Até nos meios acadêmicos ainda vemos pessoas surpresas ao ouvi-la pela primeira vez. Isso não é de estranhar, uma vez que ela começou a se firmar como disciplina acadêmica, de pesquisa séria, só a partir do início da década de noventa do século passado. Embora os modelos científicos normalmente não tenham vida longa, vinte e poucos anos são realmente muito pouco tempo para que uma nova disciplina 
científica se firme e consiga um número considerável de adeptos. No caso da ecolinguística, contudo, já podemos ver um movimento relativamente grande de seguidores pelo mundo afora, a despeito de sua pouca idade.

A surpresa ao ouvir o nome dessa nova disciplina linguística se soma a uma certa reticência pelo fato de ela vir no bojo de um movimento de conscientização sobre os problemas ambientais. Aparentemente, esse movimento começou após a publicação do livro de Rachel Carson, Silent Spring, em 1962. Além disso, no ano de 1967 um navio petroleiro deixou vazar grande quantidade de óleo ao longo da costa da Inglaterra. $\mathrm{O}$ desastre teve um destaque muito grande na imprensa, de modo que se passou a falar em "acidente ecológico", em "desastre ecológico" e "catástrofe ecológica". Em 1968, tivemos o encontro que ficou conhecido como Clube de Roma, em que se falou pela primeira sobre os limites do crescimento. Houve vários outros encontros, muitos patrocinados pela ONU. Porém, eu gostaria de lembrar o que levou à Comissão Brundtland, nome da sua presidente, com o subtítulo Nosso Futuro Comum. Esse movimento defendia a ideia de que o atendimento das necessidades da geração presente não pode comprometer o direito das gerações vindouras de atenderem as suas.

Tudo isso levou a uma proliferação de termos iniciados pelo prefixo "eco-", além de termos e expressões como "natural", "orgânico", "ambientalmente correto" etc. Culminando tudo, surgiu o termo 'ecochato' para designar aqueles que querem convencer os poluidores e devastadores dos malefícios de seus atos a longo prazo. Nesse contexto, começaram a surgir também disciplinas acadêmicas voltadas para a nova consciência. Na verdade, no âmbito da sociologia Robert Park e Ernest Burgess, da Universidade de Chicago, já falavam em 'ecologia urbana' desde o início da década de 20 do século passado. Eles procuravam explicar os problemas urbanos partindo da configuração espacial da cidade, que, segundo eles, se organizava em círculos concêntricos. Pouco depois, Riley E. Dunlap e William R. Catton propuseram a 'sociologia ambiental', falando inclusive em 'paradigma ecológico' para as ciências sociais. Temos também 
a 'psicologia ambiental', ou 'ecopsicologia', sobre a qual se pode começar lendo Günther \& Rosestraten (2005). Algo como «geografia ecológica〉 ou 〈ecogeografia〉 apareceu aproximadamente na mesma época, ou talvez até antes. Isso aconteceu também na antropologia, como se vê nos trabalhos de Julian Steward; sobre esse assunto, há um apanhado geral em Neves (1996).

Esse novo modo de pensar acabou atingindo também as ciências da linguagem, a começar de Edward Sapir. Muito antes de tudo que foi dito, ele pronunciara uma conferência sob o título de 'língua e meio ambiente' em 1911. Ela foi publicada em inglês em 1963 e em português seis anos depois (Sapir 1963, 1969). Com um grande interregno, apareceu o texto fundador da ecolinguística, Haugen (1972). Tanto que duas décadas depois a nova disciplina começaria a ganhar corpo, com a publicação de dois livros introdutórios, que são Fill (1993) e Makkai (1993). Diga-se de passagem que o primeiro já vinha falando em 'ecologia linguística' desde o início da década de oitenta. O segundo vinha fazendo reflexões nesse sentido, sob o nome de 'gramática pragmo-ecológica', desde o começo da década de setenta, tendo inclusive interagido com Haugen, que lhe sugerira oralmente a palavra 'ecolinguística' para designar esse tipo de estudo precisamente em 1972. Segundo Gobard (1976: 45), que também o menciona, o termo teria sido usado por J. D. Palmer em 1973. Esse teria sido seu primeiro registro escrito. Depois disso ele ocorreu também em Salzinger (1979) e Hagège (1985).

Foi justamente em Haugen (1972) que tivemos o que é considerado a primeira definição de nossa disciplina, embora ele estivesse falando em language ecology e ecology of language, ou seja, ele não usou a palavra 'ecolinguística' nesses textos. Sua definição da futura disciplina é a seguinte: ecologia da língua ou ecologia linguística é "o estudo das interações entre qualquer língua dada e seu meio ambiente", acrescentando que "o verdadeiro meio ambiente da língua é a sociedade que a usa como um de seus códigos" (p. 325). Esta é a conceituação de ecolinguística que se vê até os dias atuais, inclusive em Couto (2007), que já no subtítulo a define como sendo o "estudo das relações entre língua e meio ambiente". 
A despeito do fato de Haugen ser considerado o "pai" da ecolinguística, sua definição é problemática, uma vez que deixa entender que a língua é uma "coisa" que se relaciona com seu "meio ambiente". Por esses e outros motivos, eu venho preferindo conceituála como sendo o estudo das interações verbais que se dão no interior do ecossistema linguístico. Essa definição tem toda uma série de consequências, algumas das quais serão discutidas neste artigo.

\section{Mal-entendidos relativos à ecolinguística}

Gostaria de começar discutindo alguns mal-entendidos que ouvimos com relativa frequência quando falamos em ecolinguística. Um dos primeiros que ouvi foi que ela seria o mesmo que a conhecida 'hipótese Sapir-Whorf'. Convertida em tese, e em sua versão radical, ela afirma que nossa maneira de ver o mundo é determinada por nossa língua e nossa cultura. É claro que não podemos aceitar essa ideia. Nós temos contato direto com a natureza, independentemente de nossa cultura e de nossa língua. Mas, na versão moderada, ela defende a ideia de que o modo de vermos o mundo é direcionado, mas não determinado mecanicamente, pela língua e cultura a que pertencemos. A despeito de essa segunda versão fazer um certo sentido, ela é parcial. $\mathrm{Na}$ verdade, nós tendemos a ver o mundo como nossa cultura nos treinou para vê-lo. Um exemplo que tenho trazido à baila neste contexto é o das cores em tupi e guarani. Se perguntarmos a um falante dessas línguas qual é a cor da folha de uma árvore, ele dirá que é obï. Se lhe perguntarmos pela cor do céu limpo durante o dia, ele dirá, outrossim, que é obï. Daí, concluem os que defendem a hipótese, ele vê as cores por intermédio das palavras que estão à disposição em sua língua.

Como venho defendendo desde Couto (2007), a língua surge na práxis diária de seus usuários para se entenderem no meio em que vivem, a fim de falarem dele entre si. A prova ontogenética disso é a aquisição da língua pela criança. Ela fala só do que se encontra em volta de si. Tanto que nos primeiros anos ela não mente. Porém, após formada, a língua adquire uma relativa autonomia frente a esse meio, 
ao mundo, permitindo falar não só do que está presente, mas também do que está ausente e até do que ainda não existe. Permite falar mesmo do que nunca existirá. Permite criar ficção, poesia, filosofia etc. Enfim, como sempre salientou Umberto Eco, ela permite mentir. É por isso que a criança só começa a mentir a partir de certa idade, ou seja, quando começa a se inserir para valer na comunidade em que nasceu.

$\mathrm{O}$ primeiro momento, de surgimento da língua (filogenética e ontogeneticamente) é o momento onomasiológico, aquele em que se parte dos conceitos (e das coisas) e se lhe atribui um nome. Porém, como as necessidades comunicativas são inúmeras e as sociedades tendem sempre a se tornarem mais complexas, os nomes passam a ser usados para outras finalidades que não as originais, o que se pode chamar de momento da virada semasiológica. Com isso surgem as polissemias, as sinonímias, as ambiguidades, as paráfrases e toda uma série de recursos que enriquecem a língua, fazendo dela aquilo que alguns pensadores acham que é "criadora" do mundo. É claro que a visão ecolinguística inclui os dois momentos, dialeticamente. Para ela, a hipótese Sapir-Whorf é parcial, mesmo em sua versão moderada, uma vez que já parte diretamente do momento semasiológico. É algo como colocar o carro na frente dos bois.

O segundo mal-entendido que tenho visto é o de que aquilo que a ecolinguística estuda já vem sendo investigado pela sociolinguística, quer dizer, ecolinguística seria o mesmo que sociolinguística ou, na melhor das hipóteses, uma parte dela. Creio que pelo pouco que foi visto até aqui já dá para entender que isso não é verdade. A sociolinguística apresenta uma gama enorme de versões, tais como a variacionista, a interacional, a sociologia da linguagem etc. Vejamos a primeira delas, a sociolinguística variacionista, filiada às importantes pesquisas de William Labov. Ela é uma das mais fortes correntes linguísticas existentes no Brasil, talvez a mais forte, tendo atingido um alto grau de refinamento. As pesquisas que se iniciaram na Universidade Federal do Rio de Janeiro foram decisivas no estudo científico do português. No que tange à concordância (nominal e verbal), por exemplo, as pesquisas de Marta Scherre e Anthony Naro mostraram seu mecanismo interno de maneira insofismável, inclusive desmascarando muita gente 
que achava que fazia todas as concordâncias previstas no português estatal (padrão).

Sei que meus colegas sociolinguistas variacionistas não concordarão comigo. No entanto, o que se faz nessa versão da sociolinguística gira exclusivamente em torno do sistema. O que se faz é mostrar como se dá a variação no interior do sistema da língua, ou seja, que ela é sistemática, mesmo correlacionando fenômenos linguísticos com aspectos do meio social. A sociolinguística se restringe ao que chamo de ecossistema social da língua. Como veremos mais abaixo, ele é apenas um entre três ecossistemas linguísticos. A conclusão inevitável é que se quisermos relacionar as duas disciplinas temos que considerar a sociolinguística como uma parte da ecolinguística. Algo parecido poderia ser dito da psicolinguística.

A análise do discurso, pelo menos em algumas de suas versões, se aproxima bastante do que se faz em ecolinguística crítica. Tanto que os ecolinguistas dessa tendência frequentemente citam Norman Fairclough, como é o caso de Richard Alexander. Na verdade, a esmagadora maioria dos ecolinguistas é dessa linha, chegando a mais de $60 \%$ dos investigadores. Entretanto, há outras vias que são trilhadas por um número menor de pesquisadores, é verdade, mas elas existem. A começar do já mencionado Adam Makkai, que defende a tese de que a ecolinguística deve investigar não apenas a exoecologia linguística (as relações da língua com o mundo exterior a ela, inclusive questões ideológicas), mas também a endoecologia linguística (o sistema da língua). Portanto, o objeto da AD também pode ser acolhido no arcabouço geral da ecolinguística, que é holística.

Intimamente associado a isso, temos outro equívoco, que é o de se confundir ecolinguística com o estudo do ambientalismo, das questões ambientais, da crítica à devastação e poluição do nosso meio vital. Realmente existe um ramo da disciplina que poderia ser chamado de linguística ambiental, como o que faz Mühlhäusler, juntamente com outros autores (cf. Harré, Brockmeyer, Mühlhäusler, 1998), Ramos (2009) e Ferreira (2003), entre outros. Apesar de lembrar a 'sociologia ambiental' de Catton e Dunlap, a linguística ambiental é aproximadamente o mesmo domínio a que se dedica a ecolinguística 
crítica ou a linguística ecocrítica. Todas elas podem ser acolhidas no seio da ecolinguística, inclusive porque ela tem uma visão abrangente, holística, dos fenômenos da linguagem.

Um outro equívoco que se ouve de vez em quando é que a ecolinguística não é uma ciência, uma vez que pode estudar tanta coisa, o que equivaleria a não conseguir estudar nada. Além disso, ou talvez por isso, ela não teria uma metodologia própria e única. Mas, como visão holística da linguagem, ela é uma nova maneira de encará-la, e não apenas mais um modelo teórico no mercado. Ela é um arcabouço geral para se estudar todo e qualquer fenômeno relativo à linguagem. Assim sendo, não devemos falar em 'metodologia ecolinguística' como a têm a psicologia, a sociologia e outras ciências sociais, inclusive a «linguística dura» (sintaxe, morfologia, fonologia, lexicologia) e a análise do discurso. Quem comete esse equívoco vai mais longe, argumentando que se é uma ciência, a ecolinguística não decide se é uma ciência humana ou da natureza. Quem diz isso não consegue se libertar da camisa de força da visão aristotélica, cartesiana de mundo. Não percebe que uma ciência que tem uma visão abrangente de seu objeto não precisa se restringir ao maniqueísmo natura-cultura. Voltarei ao objeto da ecolinguística na seção 6, abaixo.

Por fim, gostaria de mencionar um mal-entendido resultante do fato de os estudiosos formados no espírito aristotélico-positivistacartesiano não aceitarem epistemologias englobantes, holísticas. Quando terminei de expor a questão dos 'ecossistemas linguísticos' e suas estruturas internas em uma palestra e passei a falar sobre questões de discurso (estudadas pela 'ecolinguística crítica', a 'linguística ambiental', a 'linguística ecocrítica' e, ultimamente, a 'análise do discurso ecológica'), ouvi a crítica de que teria havido uma ruptura, de que eu estaria indo numa direção, científica e, de repente, teria mudado para outra, ideológica. Enfim, o crítico em questão esperava ver uma exposição que se encaixasse perfeitamente na visão de mundo com que ele e mais de $90 \%$ da academia estão acostumados. Ele não aceitava um ponto de vista geral, abrangente, que permitisse estudar todo e qualquer fenômeno linguístico de uma perspectiva unificada. 
Ele não percebeu que inclusive sua área específica de estudo, que, se não me engano, era sintaxe gerativa, pode ser estudada no contexto dessa visão holística. A ecolinguística é trans-, inter- e multidisciplinar, do mesmo modo que a 'psicologia ambiental' (Günther; Rosestraten, 2005), por exemplo. Mais abaixo, veremos mais argumentos em prol dessa visão, mas onde há uma explanação detalhada de tudo isso é em Couto (2013).

\section{O que foi apresentado no I EBE}

Os textos aqui exibidos em forma de artigo resultam da seleção do que foi apresentado por seus respectivos autores no I Encontro Brasileiro de Ecolinguística (I EBE), realizado em julho de 2012, na Universidade de Brasília. Havia vinte dois trabalhos inscritos, inclusive de Portugal, Itália, México e Áustria. Desse total, dezessete foram efetivamente apresentados, sendo que dois deles foram expostos na modalidade de vídeo conferência. Entre os que foram apresentados, quinze compõem o presente volume, sendo que os pesquisadores Roberto e Sandra Lestinge fundiram suas apresentações em um único artigo. Havia representantes das mais diversas áreas de conhecimento, no que tange às relações entre língua e meio ambiente, entendendo 'meio ambiente' também como 'meio', 'habitat', 'biótopo', 'nicho', bem como 'território'.

A área mais representada foi, como era de se esperar, a da ecolinguística crítica (linguística ecocrítica, linguística ambiental). Foram seis apresentações, sendo que uma associa as questões ambientais à etnoecologia linguística (Francesca Zunino). Uma segunda fala de representações discursivas na fronteira (Maria Ivone Alves da Silva). Roberto e Sandra Lestinge, a exemplo de Rui Ramos, discutiram a representação de fatos antiecológicos na imprensa. Já Denize Elena Garcia da Silva, da perspectiva dos estudos críticos do discurso, associou a questão do ecologismo à ecologia humana.

Logo após, vieram as questões teóricas e as de contato de línguas, com cinco trabalhos cada. Trataram de teoria Alwin Fill, 
Samuel de Sousa Silva, Elza do Couto, Davi Albuquerque e Hildo do Couto. Com exceção do texto de Fill e do de Couto, os outros três abordaram questões teóricas, aplicadas a casos concretos. Samuel associou a relação língua-povo-território à formação da identidade do povo. Elza discutiu a importância do meio ambiente natural (espaço) para a sobrevivência da língua e da cultura de um pequeno grupo de ciganos de Goiás. Davi aplicou a teoria à endoecologia do tétum, língua franca de Timor Leste. Hildo, por fim, apresentou um panorama geral da ecolinguística.

Dos cinco trabalhos que abordaram questões de contato de línguas, o de Maria Ivone já foi mencionado, pois trata de questões discursivas em uma região fronteiriça. O texto de Ludmila Almeida e o de Altair Gomes discutem dois casos de ecossistema linguístico complexo, no caso, o multidialetalismo (o outro é o multilinguismo).

Três apresentações se enquadram no âmbito da etnoecologia linguística. A primeira, de Nathalia Costa e Dioney Gomes investiga a questão da etnoterminologia na língua munduruku. Gilberto Araújo estuda os termos etnobotânicos usados na comunidade Calunga do norte de Goiás. Eraldo da Costa, que é biólogo e atua na área das etnociências, trata de questões etnossemânticas junto aos índios pankararés, Bahia. Finalmente, temos o texto de Davi Albuquerque que, além de questões teóricas, estuda aspectos da gramática (endoecologia) da língua tétum de Timor Leste.

Entre os trabalhos submetidos ao I EBE, apresentados durante o evento, mas que não estão aqui incluídos, destacam-se dois: "O português falado na fronteira Brasil-Uruguai" (Cíntia da Silva Pacheco, UnB) e "Entrelaçamento sócio-histórico e linguístico entre guineense e caboverdiano" (Ulisdete R. S. Rodrigues, UnB). Por outro lado, entre os aprovados, mas que não foram apresentados durante o evento, cabe mencionar: "Importância das línguas indígenas em estudos etnobiológicos: o caso do México” (Rafael Serrano González, UNAM), "Comunidade surda: apontamentos sobre a ecologia fundamental da língua na LIBRAS (Kelly Pereira de Cruz, UFG), "Preconceito linguístico e ecolinguística crítica: entre o fazer e o dito" (Laís Carolina Machado da Silva, UFG), "Etnoecologia linguística, ou 
etno-ecolinguística, ou ecoetnolinguística? Aspectos terminológicos dos estudos sobre língua e meio ambiente" (Darto Vicente da Silva, UnB).

\section{4. Áreas de pesquisa na ecolinguística}

O texto "Palavras Iniciais" de Alwin Fill, que inicia este volume, bem como os trabalhos apresentados e discutidos no I EBE, já sinaliza algumas das principais áreas de pesquisa no domínio da ecolinguística. Juntando-os aos que se veem nas publicações estrangeiras, sobretudo no circuito Alemanha-Áustria, podemos levantar um elenco provisório do que se tem feito nessa disciplina. Algumas dessas produções são explicitamente ecolinguísticas, ou seja, seus autores se consideram ecolinguistas, uma vez que partem de conceitos ecológicos. Outros nem tanto, uma vez que, apesar de tratarem de temas que para a maioria dos investigadores da área seriam ecolinguísticos, seus autores não os consideram como tais. Isso talvez valha sobretudo para áreas conexas. Vou começar pelas áreas mais bem representadas na pesquisa ecolinguística, que são a ecolinguística crítica, muito próxima da análise do discurso ecocrítica, e a linguística ambiental.

A ecolinguística crítica está bem representada nos encontros que se realizam no contexto da AILA e da GAL (Gesellschaft für Angewandte Linguistik = Associação de Linguística Aplicada, Alemanha), bem como fora dessas duas organizações. Vou levar em consideração apenas os trabalhos que foram publicados em coletâneas. Nas duas primeiras (Fill, 1996; Kettemann; Penz, 2000) as contribuições não estão classificadas por temas. Isso começou a ocorrer a partir da terceira, que é Fill; Mühlhäusler (2001). Nela há uma seção, a maior, intitulada "Critical Ecolinguistics" (Parte 4), subdividida em duas subseções.

A primeira é "Ecocriticism of the Language System", que começa com o texto "clássico" de Halliday intitulado "New ways of meaning: The challenge of Applied Linguistics", originalmente apresentado no encontro da AILA na Grécia, em 1990. Como o título já sugere, o texto 
critica a "estrutura" de nossas línguas que, para o autor, é altamente antiecológica. A seção contém também um texto de Wilhelm Trampe, que examina a questão da crise ecológica vislumbrável em extratos de um dicionário dedicado à agricultura industrial. Um outro texto é de Andrew Goatly, que discute a visão fragmentada do mundo que as línguas ocidentais implicam, dividindo-o em processo, participantes e circunstâncias. Em sua opinião, a gramática deveria mostrar o mundo de modo integrado, holístico. Em seguida vem uma réplica a ele feita por Mary Schleppegrell e a tréplica de Goatly.

A segunda subseção contém quatro textos. O primeiro trata da voz passiva (Mary Kahn), que seria uma estratégia de o agente se omitir. O segundo é de Michael Howlett e Rebecca Raglon, mostrando que as propagandas americanas de 1910 a 1990 não contêm nada de novo, a não ser o desejo de mostrar as empresas divulgadas como ambientalmente corretas. O texto de Tzeporah Berman é bastante radical, uma vez que associa o estupro da mulher à devastação da natureza pelo homem. O último texto é de Matthias Jung. Ele relativiza o poder que a linguagem poderia ter sobre o meio ambiente, afirmando que a língua humana só poderia ser 'antropocêntrica' e que jamais poderíamos saber qual é a visão que outras espécies têm da natureza.

$\mathrm{Na}$ linha da linguística ambiental, temos, além de Harré; Brockmeier; Mühlhäusler (1998), a Parte 3 da antologia em questão, intitulada "Language and Environment" (Língua e Meio Ambiente), além de Ramos (2009) e Ferreira (2003). O assunto de todos esses textos se aproxima muito do da ecolinguística crítica, como já vimos. Aliás, até alguns textos de outras seções vão na direção de uma análise do discurso ecocrítica. Nos últimos tempos, está-se configurando uma linha de investigação que tem recebido o nome de linguística ecossistêmica crítica ou análise do discurso ecológica (Couto, 2013).

A terceira coletânea (Fill; Penz; Trampe, 2002) contém 28 contribuições, distribuídas por cinco seções. A que interessa no momento é "Eco-Critical Discourse Analysis" (seção 3), ou seja, "Análise do Discurso Ecocrítica", com nove ensaios, a maior de todas. Vários textos que aparecem sob outras rubricas entrariam em uma das áreas da ecolinguística crítica. A exceção seria o primeiro, 
que trata de questões teóricas, e o segundo, dedicado ao contato de línguas. O volume seguinte (Fill; Penz, 2007) é dedicado ao que os organizadores chamaram de ecolinguística aplicada. Ele tem também a ver em grande parte com a questão da sustentabilidade, quando encarada da perspectiva linguística. Como não poderia deixar de ser, a maior parte dos textos é de ecolinguística crítica. Os doze textos da última coletânea a que tive acesso (Döring; Penz; Trampe, 2008) vão pelo mesmo diapasão das anteriores, mesmo se propondo tratar dos signos em geral e da natureza, com o que já entraria pelo domínio da ecossemiótica, sobre a qual se pode ler (Couto, 2007: 423-433). Mas, há bons ensaios teóricos entre eles.

Uma linha de pesquisa que merece um destaque especial é a ecolinguística dialética, praticada pela Escola Ecolinguística de Odense, Dinamarca, cujos principais membros são Jørgen Døør, Jørgen Christian Bang, Sune Steffenson e Anna Vibeke Lindø. Essa escola trabalha com três dimensões (natural, mental, social), que correspondem aos nossos ecossistemas natural, mental e social. Enfim, eles têm uma visão efetivamente holística da realidade da linguagem, tanto que se dedicam não apenas a examinar discursos (anti)ecológicos. Eles estudam também questões de endoecologia linguística. Existem textos desses autores em praticamente todas as antologias recém-mencionadas.

Uma linha de investigação a que não se dá muita atenção até mesmo nos meios ecolinguísticos é o que em Couto (2007) chamei de etnoecologia linguística. Ela está muito bem representada pelo grupo que se junta em torno da ONG Terralingua, coordenada por Luisa Maffi (cf. Maffi, 2001). Inclusive Mühlhäusler já participou dela. Grande parte do que eles fazem já vinha sendo investigado pelas etnociências, área a que pertence Eraldo Costa, que tem um texto no presente volume. No livro que acaba de ser mencionado eu proponho que a etnoecologia linguística é o ramo da ecolinguística que se dedica à linguagem dos pequenos grupos étnicos e grupos isolados do interior do país, como os calungas do norte de Goiás. Entre os tópicos que podem ser estudados nessa área está a linguagem dedicada à etnobotânica, à etnozoologia, à etnomedicina, à etnotoponímia e 
à etnoantroponímia, entre outras. Todas elas constituem capítulos inteiros em Couto (2007). Nesse contexto, temos a etnoterminologia de Costa \& Gomes (este volume). Sarmento (2002) já falava em ecolexicologia e ecolexicografia. Sarmento (s/d) está disponível online.

Uma outra linha de investigação ecolinguística que pode ser mencionada é a ecologia da evolução linguística, representada principalmente por Mufwene (2001), a despeito de ele não se considerar ecolinguista. Eu mesmo dediquei um capítulo a ela, além de um ensaio menor (Couto, 2008). Este último tentou mostrar que as causas para sequências silábicas como "car.tu.cho", "cer. ve.ja", "for.na.lha", "ca.mi.nho", "ca.té.ter" e outras não poderem ser proparoxítonas seria a existência de algum tipo de memória de fatos anteriores da língua, mesmo quando eles não se realizem mais foneticamente. Seria praticamente impossível explicar o fato sem levar em conta a sucessão ecológico-linguística.

Nesse contexto, não se pode deixar de lado a ecologia da aquisição de língua. Ela está muito bem representada em Kramsch (2002) e Leather; van Dam (2003). Basicamente, o ensino/aprendizagem de língua é visto como um processo de adaptação à comunidade em que o aprendiz cresce (L1), ou à qual ele pretende se dirigir (L2), ou na qual se insere após adquirir sua L1. A tese de doutorado de Ronaldo Lima Júnior (A influência da idade na aquisição da fonologia do inglês como lingua estrangeira por brasileiros), defendida na UnB em dezembro de 2012, contém dados sobre essa abordagem, inclusive via sistemas complexos. Não podemos esquecer também a ecologia do contato de línguas, objeto de estudo do próprio pai fundador da ecolinguística, Einar Haugen, e de Francis Mackey. Em português, temos Couto (2009).

Se pensarmos no ecossistema mental da língua, poderíamos mencionar ainda a neurolinguística, uma vez que ela investiga como a língua se forma e é processada nas conexões neurais que se dão entre dendritos e axônios no interior do cérebro humano. Poderíamos aduzir ainda a teoria linguística que surgiu como 'gramática estratificacional' (Couto, 1982) e que hoje é chamada linguística neurocognitiva (Lamb, 
2000). Ela procura representar os processos linguísticos em termos de redes, que estariam em uma relação icônica com o que se passa nas conexões neurais, o que a aproxima do conexionismo. Assim sendo, a ecolinguística deve levar em conta as pesquisas neurolinguísticas.

Creio que vale a pena terminar citando duas áreas conexas da ecolinguística, a ecocrítica e a ecossemiótica, que constituem os dois últimos capítulos de Couto (2007). Embora não sendo parte dela, há algum intercâmbio entre partidários delas e da ecolinguística. No que tange à ecossemiótica, é bom lembrar que a coletânea organizada por Döring; Penz; Trampe (2008) se dedica em grande parte à questão dos signos. Tanto que um dos mais conhecidos ecossemioticistas, Winfried Nöth, está presente nela com o texto "Natural signs and the natural ingredients of cultural signs". É dele a definição de ecossemiótica que reproduzo em meu livro. Ele sugere que ecossemiótica "é o estudo das relações semióticas mútuas entre os organismos e seu meio ambiente". A ecocrítica aparece em Fill; Penz; Trampe (2002). Os eventos de ecocrítica têm incluído seções sobre ecolinguística. No penúltimo capítulo de meu livro recém-mencionado vê-se que ecocrítica é o estudo das relações entre textos literários e o meio ambiente físico.

A última vertente da ecolinguística que eu gostaria de discutir é a linguística ecossistêmica. A seção 7 apresentada mais adiante será inteiramente dedicada a ela.

\section{Ecolinguística como nova maneira de encarar os fenômenos da linguagem}

Vimos que a ecolinguística não faz uma mera transposição mecânica e ingênua de conceitos da ecologia para o domínio dos fenômenos da linguagem. Sequer faz ela um "uso criativo" desses conceitos, usando-os em outro contexto, no qual teriam outras "funções", como eu próprio dizia até pouco tempo atrás. Na verdade, ela estuda ecossistemas. Isso vale tanto mais para a linguística ecossistêmica. Com efeito, linguagem é ação, e ação envolve energia. É o tipo de energia que Humboldt denominara enérgeia (Tätigkeit), no 
que foi apoiado pelo filósofo e ecolinguista Peter Finke. Se o objeto da ecolinguística é um tipo especial de ecologia, de ecossistema, ela está em sintonia com as versões mais recentes da ciência moderna, tais como a teoria do caos, a teoria dos sistemas, as estruturas dissipativas, a teoria de tudo etc. Se pensarmos naquilo que para Chomsky é uma das características da linguagem humana, a recursividade, notaremos que muitos aspectos da endoecologia da língua lembram a teoria matemática dos fractais, proposta por Benoit Mandelbrot. Essa teoria mostra que fenômenos aparentemente caóticos podem ser reduzidos a princípios elementares, como os gases e os flocos de neve. Talvez o encadeamento de palavras em frases e de frases em textos estejam neste caso.

No epílogo a Capra (2002), o autor fala de uma visão orgânica do mundo. De acordo com essa visão, "os componentes da matéria e os fenômenos básicos envolvendo esses componentes estão interligados; [...] eles não podem ser compreendidos como entidades isoladas, mas apenas como partes integrais de um todo unificado". O autor acha que a nova visão deve ser incluída no 'paradigma ecológico' ou "visão de mundo ecológica". Essa visão de mundo é abrangente, holística. Para ele, o todo não é a uma mera soma das partes, como na mecânica clássica, que o via como uma totalidade estática e fechada. Ele é dinâmico, aberto e tem propriedades que não se encontram em nenhuma delas, é maior do que a mera soma delas.

Atitude semelhante deve ser assumida pelo ecolinguista. Ele deve mudar seu modo de encarar o mundo e a linguagem. Como disseram Einstein e Peirce, é mais fácil matar um homem do que lhe arrancar as crenças. Mas, o ecolinguista procura mudá-las. Em vez de olhar para seu objeto apenas por janelas (como a da sociolinguística, a da psicolinguística, a da análise do discurso, a da teoria sintática ou fonológica etc.), procura postar-se na cumeeira da casa, de onde terá uma visão global, holística de seu objeto, não o pequeno domínio visto da janela. Se em determinado momento precisar de dados minuciosos como a palatalidade consonantal ou algo semelhante, ele pode contratar os serviços de um fonólogo (ou ele mesmo executa o serviço, se tiver o conhecimento específico necessário). De mãos do resultado, retorna 
à cumeeira da casa a fim de avaliar os dados obtidos no contexto maior em que se encontra. Se ele se colocar no alto de uma montanha, como faz o linguista ecossistêmico, terá uma visão mais abrangente ainda. Uma vez que as disciplinas parcelares que lhe prestam serviços especializados vão com as respectivas metodologias, se quisermos falar em metodologia em ecolinguística, em ecometodologia, ela só poderia ser multimetodológica e ter um caráter avaliativo dos resultados trazidos pelas disciplinas parcelares. Para tanto usa, como sempre, critérios e conceitos ecológicos. Aliás, seria interessante notar que Günther \& Rosestraten (2005) dizem aproximadamente o mesmo sobre a 'psicologia ambiental' (um tipo de 'ecopsicologia'). Para eles, ela é 'interdisciplinar' e 'multimetodológica'. A única exigência é que se deve proceder sempre partindo da visão de mundo ecológica, como se pode ver mais detalhadamente em Couto (2013).

A ecolinguística seria uma base ou plataforma, a partir da qual se poderia decolar para o estudo de qualquer fenômeno linguístico, mas sempre tendo por "base" a ecologia. É dela que se parte e é a ela que se retorna. No entanto, como disse o epistemólogo Mario Bunge, é preciso que tenhamos o conhecimento profundo de uma disciplina parcelar também, como as já mencionadas. Isso nos dará disciplina e autoconfiança, mesmo quando encaramos a linguagem holisticamente. Enfim, ter uma visão holística do objeto de estudo não é o mesmo que querer abranger muita coisa ou tudo. Querer abranger tudo significaria ter a pretensão de praticar uma 'teoria de tudo' em linguagem, como se diz na física (theory of everything). Pelo contrário, aqui se trata de uma outra maneira de encarar os fenômenos linguísticos. Poderíamos até estudar a palatalidade dos fonemas /s/ e /t/ na região de Uberaba (MG), mas sem esquecer que os dois fazem parte de uma sílaba, que faz parte de um morfema, que é parte de uma palavra, que é parte de uma frase, que é parte de um texto, que é parte de uma interação comunicativa e assim por diante, até chegar às interconexões do universo. É estudar uma árvore sem esquecer que ela é parte de uma floresta. Como já observado, a ecolinguística é um arcabouço geral para se estudarem os fenômenos da linguagem. 


\section{O que é ecolinguística e qual é o seu objeto?}

Diante de um quadro aparentemente tão heterogêneo, embora eu prefira dizer amplo, é de se perguntar o que é ecolinguística no final das contas, qual é seu objeto de estudo. Vimos que a definição original de Haugen, que vem sendo repetida ao longo dos tempos, é problemática. O principal problema é que pressupõe que haja duas "coisas": de um lado a "coisa" língua, de outro a "coisa" que é o seu 'meio ambiente'. Embora seja usada pela maior parte dos ecolinguistas que vieram depois, essa definição reifica a língua, atitude inaceitável depois que a teoria da relatividade e a própria ecologia mostraram já na década de vinte do século passado que toda a realidade é uma imensa rede de interconexões. A língua não constitui exceção a isso. Além do mais, Haugen restringiu esse 'meio ambiente' a apenas um, sendo que se podem detectar pelo menos quatro, como vimos na seção anterior (fundamental > natural, mental, social).

Todos esses problemas surgiram pelo fato de Haugen ter partido de conceitos ecológicos como 'metáforas' para se estudarem fenômenos da linguagem. Assumindo a postura ecolinguística e, sobretudo, a da Escola Ecolinguística de Brasília, e como foi sugerido por Garner (2004), notamos que, na verdade, a língua é uma teia de interações, logo, é um ecossistema e parte de outros ecossistemas. Esse ecossistema contém ecossistemas em seu interior. A gramática estratificacional ou linguística neurocognitiva estudava pelo menos a endoecologia linguística. Quem pratica linguística ecossistêmica não está pinçando conceitos da ecologia biológica e os inserindo nos estudos linguísticos, como eu mesmo fazia até certo tempo. Pelo contrário, está estudando ecologias ou, como o núcleo da ecologia é o ecossistema, está estudando ecossistemas, no caso, ecossistemas linguísticos. Para se ter uma ideia do lugar da ecolinguística no contexto da ecologia geral (macroecologia), vejamos o quadro da figura 1 . 


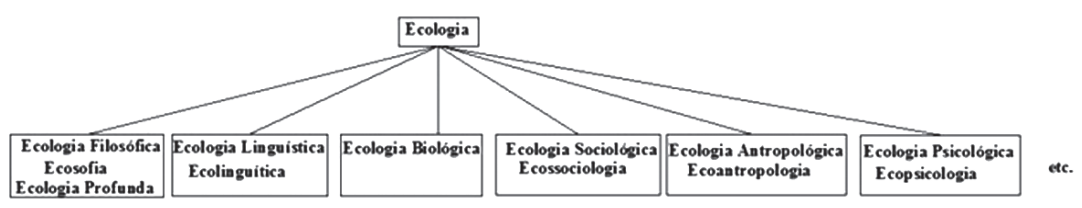

Figura 1

Pela Figura 1 pode-se observar que a ecolinguística é um dos ramos da ecologia geral. O principal é a ecologia biológica, que se encontra no centro. No entanto, há diversas outras ecologias, como a filosófica, a linguística, a sociológica, a antropológica e a psicológica, para mencionar apenas algumas. Focando a atenção especificamente na ecologia linguística, podemos ver como ela encara os fenômenos linguísticos em sua totalidade partindo da figura 2 .

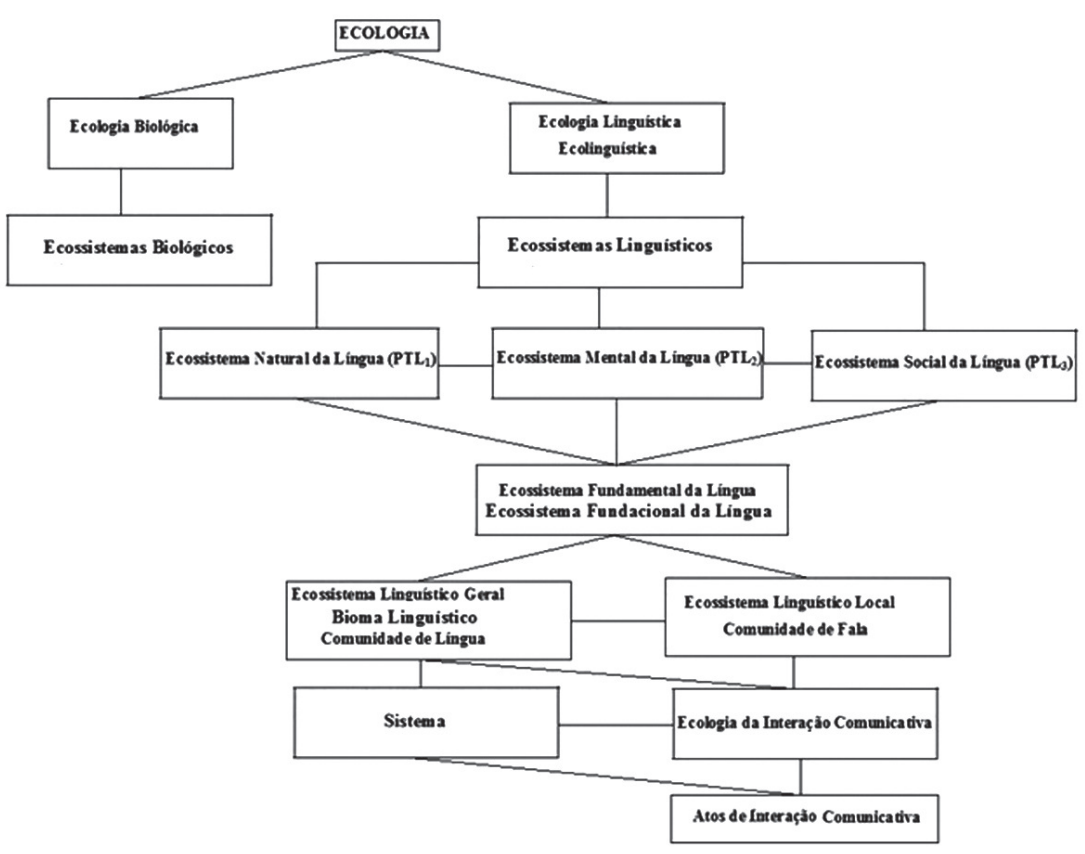

Figura 2 
A Figura 2 acima sinaliza que a ecologia linguística (outro nome para ecolinguística) é uma das maneiras de se fazer ecologia. Deixando as demais de lado para efeitos operatórios, notamos que seu objeto de estudo são os ecossistemas linguísticos, que inicialmente compreendem o ecossistema natural, o mental e o social. Em consonância com a proposta de Leonardo Boff de que esses três ecossistemas (que ele chama de 'ecologias') convergem para um ecossistema 'integral' (Boff, 2012), na linguística ecossistêmica eles convergem para o que chamo de ecossistema fundamental da língua, mas que poderia ser igualmente chamado de ecossistema fundacional da língua, por razões óbvias. Este, por seu turno, pode ser encarado da perspectiva da comunidade de língua e da da comunidade de fala. A primeira, também chamada de ecossistema linguístico geral e bioma linguístico, equivale ao domínio do sistema. No caso do português, todos os lugares em que esse sistema se fizer presente (Portugal, Brasil, Angola, Moçambique, Cabo Verde, Guiné-Bissau, São Tomé e Príncipe, Timor Leste) fazem parte do sistema da comunidade de língua portuguesa, independentemente de ele estar sendo usado no momento ou não. Tanto que poderíamos chamá-la também de comunidade de sistema.

A segunda, comunidade de fala, ou ecossistema linguístico local, às vezes é chamada de comunidade de interação na linguística alemã. Ela é o nicho em que se insere a ecologia da interação comunicativa, no seio da qual são produzidos atos de interação comunicativa concretos. Como se pode ver, o sistema é um dos ingredientes que entram em ação na produção desses atos. Eles não são mera realização dele, o sistema é que é parte dos atos de interação comunicativa, como sempre salientou Coseriu. Veremos que eles envolvem 'regras interacionais' e 'regras sistêmicas', além do contexto.

Dos atos de interação comunicativa emergem textos, em geral orais, mas eles podem ser também escritos. Esses textos podem ser estudados de diversos pontos de vista, inclusive "ideologicamente", no caso, uma 'ideologia ecológica', como veremos na seção 7. De qualquer forma, é importante ter em mente que cada "quadro" e/ou nível da figura 2 representa 'aspectos' pelos quais a questão da linguagem 
pode ser encarada, seguindo a terminologia do filósofo espanhol José Ortega y Gasset. O importante a reter aqui é que a ecolinguística nos permite estudar todo e qualquer 'aspecto' dos fenômenos linguísticos, mas sempre usando e epistemologia ecológica, uma vez que a ecologia linguística é uma parte da ecologia geral. Nós praticamos ecologia, ecologia linguística, ou ecolinguística. Mais especificamente, linguística ecossistêmica $(2012,2013)$.

Neste momento, podemos propor uma definição provisória tanto para língua como para a ciência que se dedica a ela, no nosso caso, a ecolinguística. Levando-se em conta que a língua é uma rede ou teia de interações, podemos defini-la como sendo o modo costumeiro de se interagir verbalmente no interior de um ecossistema linguístico, ou comunidade, definição que está em sintonia até com o que já defendia o linguista estruturalista Eugenio Coseriu. Esse é o objeto da ecolinguística, sobretudo a ecossistêmica. A língua é interação não só em sua exoecologia, mas também endoecologicamente. Com isso, a definição de ecolinguística emerge naturalmente. Ela é a disciplina que estuda o modo costumeiro de os membros de uma comunidade interagirem verbalmente entre si. Podemos conceituá-la também como sendo o estudo da linguagem humana como interação sob todos os aspectos.

Como se pode notar, o objeto da ecolinguística é constituído por toda e qualquer manifestação linguística, uma vez que ela o encara de maneira holística. Parafraseando Terêncio e Jakobson, poderíamos dizer: Ecolinguista sum, linguistici nihil a me alienum puto (eu sou ecolinguista e nada do que é linguístico me é estranho).

\section{Linguística ecossistêmica}

Na mesma época da realização do I EBE, foi sugerido um nome para o modo como se vinha praticando ecolinguística em torno da Universidade de Brasília. O movimento começou com as dissertações mestrado de Almeida (2004) e Melo (2005). Logo em seguida, os mesmos pós-graduandos defenderam suas teses de doutorado (Melo, 
2008; Almeida, 2008). Infelizmente, nenhum dos dois continuou na ecolinguística, por razões profissionais. Felizmente, porém, outros pós-graduandos começaram a fazer pesquisas nesse âmbito. Gilberto P. Araújo está investigando os nomes de plantas junto aos calungas do norte de Goiás, aplicando a etnoecologia linguística. Davi B. Albuquerque está estudando a língua portuguesa em Timor Leste, em relação com as línguas locais (como tétum), aplicando a endoecologia linguística.

No início de 2013, Helem Andressa de Oliveira Fogaça entrou para nosso programa de pós-graduação em linguística para desenvolver o projeto "A Ecologia das Línguas do Timor-Leste: Situação da Diversidade e Vitalidade Etnolinguística”. A partir de meados de 2009, Elza K. do Couto (da UFG) desenvolveu uma pesquisa de pós-doutorado de um ano de duração sobre a língua dos ciganos kalderash de Aparecida de Goiânia sob minha supervisão. No início do ano de 2012, ela começou a ministrar aulas de ecolinguística em sua universidade, em nível de graduação. Um dos frutos mais visíveis dessa atividade foi a participação de diversos alunos seus no I EBE. Por fim, em julho de 2013 Kênia Mara de Freitas Siqueira também iniciou um programa de pós-doutorado comigo, com um projeto sobre os topônimos de origem indígena do estado de Goiás, da perspectiva ecolinguística.

O fato é que esse movimento, que inclui professores e alunos de outras instituições de outros estados, passou a ser chamado de Escola Ecolinguística de Brasília. A variedade de ecolinguística que ela pratica começou a ser chamada de linguística ecossistêmica, por motivos expostos no que subsegue. Como o próprio nome sugere, a ecolinguística que praticamos tem por base o ecossistema. Os demais ecolinguistas também usam conceitos ecológicos, mas como metáfora. Nós, ao contrário, praticamos a própria ecologia. Se os biólogos estudam a ecologia biológica, nós estudamos a ecologia linguística, mais conhecida como ecolinguística. Do mesmo modo que há ecossistemas terrestres (tundra, taiga, savana etc.), lacustres, marinhos e outros, há ecossistemas linguísticos. Como sabemos, o conceito central da ecologia é o de ecossistema (figura 3a), que 
consta de uma população (P) de organismos, convivendo em seu habitat (biótopo, nicho, meio, meio ambiente, entorno) ou território (T), juntamente com as inter-relações ou interações (I) que se dão (a) entre organismos e T, bem como (b) entre quaisquer dois organismos.

Como ecolinguistas partimos do ecossistema linguístico, começando pelo natural, o mental e o social, que estão incluídos no ecossistema fundamental/fundacional da língua (3b). O C está para 'cultura', a totalidade daquilo que significa alguma coisa para os membros da comunidade. É tudo aquilo que faz parte de seu meio e que não é só um dado natural, mas construído ou apropriado pela comunidade como parte de seu acervo de signos. Em Couto (1981), considerei C como um "conjunto-universo de códigos", baseado na Estrutura ausente de Umberto Eco. São as 'relações sociais' de Lévi-Strauss (1970) e equivalem ao I da ecologia biológica. A língua (L) é uma parte desse universo. A C pertence tudo que faz com que as interações entre dois membros da comunidade sejam eficazes, uma vez que tudo na cultura pode ser usado nos atos de interação comunicativa. No interior desse ecossistema (3b), P e T juntos formam o meio ambiente fundamental da língua.

Já que a língua é interação, ecolinguisticamente as interações entre um ou mais organismos e o meio (a) são as relações de significação, referência, designação. As interações entre quaisquer dois organismos no seio do ecossistema linguístico (b) constituem a comunicação. O total são as 'relações sociais' e seus signos. Portanto, C é a totalidade dos meios de significação e comunicação de um povo, aí inclusa a língua.

Aqui não se trata de língua, de povo nem de território específicos, mas de modo geral, como quando dizemos que para que haja um língua é necessário que pré-exista um povo que a fale, com toda a sua cultura, e que esse povo só terá essa língua se conviver em determinado território, sem especificar quais são esse povo, essa língua/cultura ou esse território. Trata-se de uma perspectiva holística, abrangente, que pode ser assim representada: 
Cadernos de Linguagem e Sociedade, 14 (1), 2013

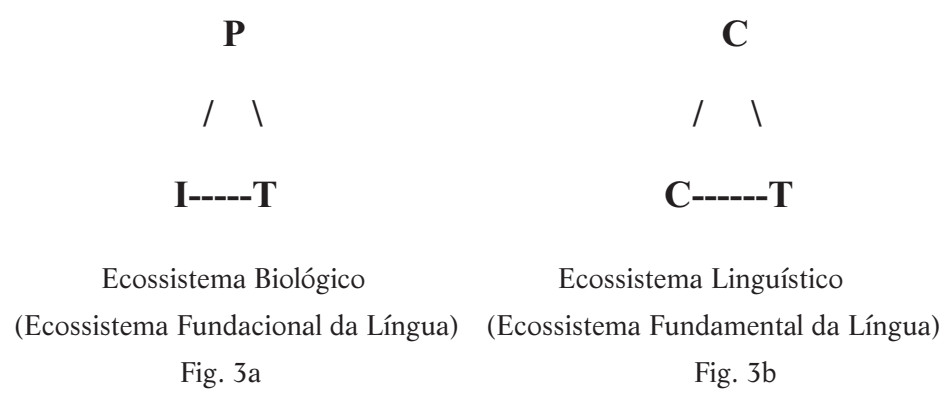

No que concerne às representações acima, sigo as propostas dos ecolinguistas Jøgen Døør e Jørgen Christian Bang (da Escola Ecolinguística de Odense), as do filósofo (Guattari, 2011), que prevê três "ecologias" bem como as do filósofo brasileiro Leonardo Boff (Boff, 2012), que também reconhece um quarto ecossistema, o integral, equivalente ao meu fundamental. Por outro lado, cabe destacar que, recentemente, tomei conhecimento da "Mandala da Gramática da Experiência", sugerida por Silva (neste volume), adaptada de uma proposta de Halliday. No interior da referida mandala, há três dimensões fundamentais: a do "mundo físico" (FAZER), a do "mundo da consciência" (SENTIR) e a do "mundo das relações abstratas" (SER). Elas são equivalentes perfeitos dos três ecossistemas linguísticos aqui propostos (natural, mental, social), como a própria autora reconhece em seu artigo.

$\mathrm{O}$ ecossistema fundamental da língua contém três outros em seu interior, representados na figura 2 abaixo. O primeiro deles é o ecossistema natural da língua (4a), constituído por determinado povo $\left(\mathrm{P}_{1}\right)$, convivendo em sua terra $\left(\mathrm{T}_{1}\right)$ e se comunicando pelo modo normal de se comunicar localmente, ou seja, por sua língua $\left(\mathrm{L}_{1}\right)$ específica. A diferença entre ele e o ecossistema fundamental da língua é que no 'natural' $\mathrm{P}_{1}$ e $\mathrm{T}_{1}$ são encarados como entidades físicas, naturais, e $\mathrm{L}_{1}$ são as relações concretas, naturais que se dão entre eles. $\mathrm{T}_{1}$ é a base física, o locus material, 'natural' para a existência de $\mathrm{P}_{1}$ (o conjunto de indivíduos como seres físicos) e suas interações $\left(L_{1}\right)$ concretas. Por isso, o ecossistema natural da língua é um ecossistema real, que consta da língua $\mathrm{x}$, falada pelo povo $\mathrm{y}$, que se encontra no 
território z. Tudo que tem a ver com a língua como fenômeno natural entra aqui. Deve-se ressaltar que, nesse caso, língua é uma realidade basicamente biológica, natural, relacionada com o mundo físico. $\mathrm{P}_{1} \mathrm{e}$ $\mathrm{T}_{1}$ juntos constituem o meio ambiente natural da língua.

Em (4b), temos o ecossistema mental da língua. Se entendermos 'mente' como o cérebro em funcionamento, então $\mathrm{P}_{2}$ é mente. Quanto a $T_{2}$ está para a massa encefálica que é o suporte da mente. É o cenário (o locus), a base das interações mentais, do psiquismo, ou seja, é o cérebro de cada indivíduo. Trata-se fundamentalmente das conexões neurais em que se inscreve a língua, ou seja, em que ela é formada, armazenada e processada. $\mathrm{P}_{2}$ e $\mathrm{T}_{2}$ juntos formam o meio ambiente mental da língua. Quem estudou esse ecossistema detalhadamente foi Gregory Bateson, além da teoria da gramática gerativa, pelo menos no que tange especificamente às relações intermorfêmicas, intervocabulares e interfrasais. Poderíamos incluir aí também a filosofia de Edmund Husserl. É um dos ecossistemas menos estudados no âmbito da ecolinguística.

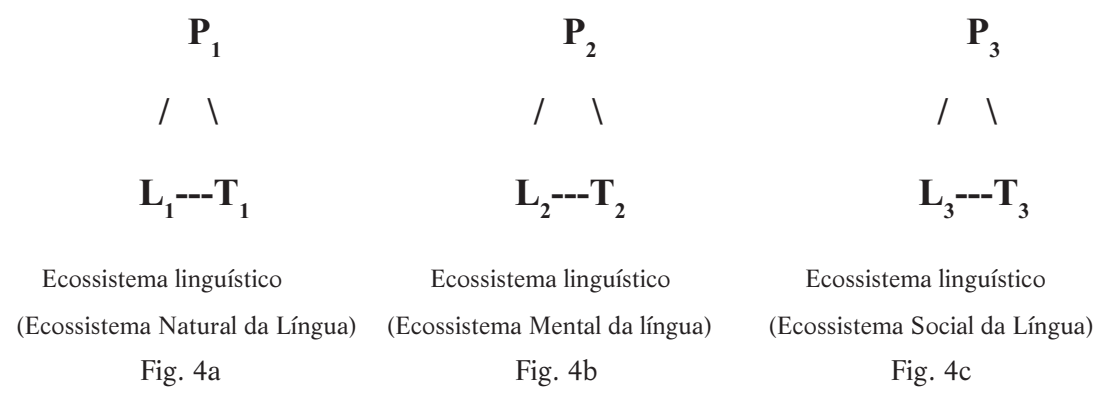

Por fim, temos o ecossistema social da língua (figura 4c). No caso, $\mathrm{L}_{3}$ é a língua como fenômeno social, como grande parte das pessoas a vê (para a maioria, ela é um fenômeno exclusivamente social). $\mathrm{P}_{3}$ é a totalidade dos indivíduos da comunidade como seres sociais (interindividualidades, intersubjetividades), a coletividade. $\mathrm{T}_{3}$ é o cenário o locus, a "organização" em que se encontram essas individualidades sociais, a sociedade. No interior desse ecossistema 
linguístico, $\mathrm{P}_{3}+\mathrm{T}_{3}$ formam o meio ambiente social da língua. A linha segmentada aponta para o fato de que a língua como fenômeno social se relaciona com a sociedade $\left(\mathrm{T}_{3}\right)$ por intermédio da coletividade de indivíduos sociais $\left(\mathrm{P}_{3}\right)$ que a constituem.

Vê-se, portanto, que a língua pode ser encarada pelo menos de quatro perspectivas diferentes. Primeiro, como algo abrangente (a 'ecologia integral' de Boff), holístico e fundamental no ser humano, caso em que é parte de um todo maior, que é a cultura (C) do povo a que ela serve. Segundo, como algo natural, que faz uso de dados da natureza, como os sons, e está ligada a ela nas relações de referência e descrição $\left(\mathrm{L}_{1}\right)$, entre outras. Terceiro, como algo que é formado e processado nas conexões neurais, ou seja, algo mental $\left(\mathrm{L}_{2}\right)$. Quarto, como o que o leigo geralmente pensa, isto é, como uma realidade social $\left(\mathrm{L}_{3}\right)$. Trata-se de 'aspectos' do fenômeno linguagem, de diferentes modos de encarálos. Assim sendo, são parciais praticamente todos os modelos teóricos que têm sido propostos para estudar a língua. Todos são reducionistas. Alguns se restringem a questões filosóficas fundamentais. Outros consideram-na um fenômeno apenas mental. Outros, por fim, veem nela algo exclusivamente social. Na verdade, a língua é tudo isso. Ela é uma realidade biopsicossocial. Como vista aqui, a língua não é reificada, ela não é algo (uma coisa) que tem uma "função" (comunicação, expressão do pensamento). Pelo contrário, ela é vista como uma rede de interações (naturais, mentais, sociais). Enfim, a língua não tem por função a comunicação, ela é comunicação. Talvez essa aparentemente complexa teia de interações linguísticas fique mais clara examinando-se o quadro da figura 2, mostrada acima.

É por lidar sempre com ecossistemas, representados nas figuras de 3 e 4, que a variedade de ecolinguística praticada por nós passou a ser chamada de linguística ecossistêmica. Como há ecossistemas dentro de ecossistemas, e como todo ecossistema é composto de "partes" (que também são interações ecossistêmicas), é preciso distinguir exoecologia de endoecologia. A primeira se dedica às relações da língua com seu meio, ou seja, com outras línguas, com os usuários, com o território etc. É o que a tradição considerava como atribuição da linguística externa. A endoecologia, por seu turno, inclui tudo que for interior à língua, 
como questões de gramática, de léxico etc. É por isso que dizemos que a linguística ecossistêmica não se restringe a estudar questões de ambientalismo e correlatas. Ela vê a língua efetivamente como um todo, de modo abrangente. Como não há espaço para discutir o assunto pormenorizadamente, remeto o leitor a Couto (2012).

Foi dito diversas vezes acima que a linguística ecossistêmica abriga também estudos de ecolinguística crítica, linguística ambiental e/ou linguística ecocrítica. Pois bem, gostaria de encerrar este tópico chamando a atenção para o fato de que na ecologia geral e em suas subdivisões (biológica, sociológica, filosófica etc.) temos grande parte dos conceitos (se não todos) que se fazem necessários nesse tipo de estudo. Um dos primeiros e mais conspícuos entre eles é o de diversidade. Com efeito, sua aceitação implica uma atitude de tolerância para com o outro, sobretudo quando é diferente. A não aceitação implica intolerância, o que pode conduzir à agressividade e à violência, sobretudo contra as minorias de todos os tipos. Sua aceitação pressupõe uma política de cooperação e harmonia. O contrário seria a subordinação dos mais fracos aos mais fortes e a consequente imposição da vontade dos segundos sobre os primeiros. Como se vê, aqui entra a questão do poder.

Temos ainda os conceitos de reciclagem, abertura/porosidade, holismo, adaptação, evolução, visão de longo prazo e sustentabilidade, entre outros. Reciclagem tem a ver diretamente com o consumismo capitalista desbragado. Só recicla quem tem consciência de que o consumismo e a descartabilidade são prejudiciais à manutenção da vida na face da terra, sobretudo a longo prazo. Para agir assim, é necessário que se pratique uma economia sustentável, que leve a ecologia em consideração. Além disso, é preciso encarar o objeto de estudo como um todo, de modo holístico, uma vez que nada neste mundo está isolado. No entanto, esse todo é sempre aberto, poroso, já que influi e sofre influência do que está em sua volta, imediata e mediatamente. O mundo e a cultura (inclusive a língua) são dinâmicos, estão sempre mudando, evoluindo, com o que os seres vivos (e não só eles) têm que estar sempre se adaptando às novas situações que a natureza (e a cultura) lhes apresenta. 
Outros conceitos ecológicos de que se pode lançar mão no caso presente são os de relações harmônicas versus relações desarmônicas, tanto intraespecíficas quanto interespecíficas. Entre as relações harmônicas interespecíficas, poderíamos mencionar o inquilinismo, o comensalismo e o mutualismo. No que tange às relações desarmônicas interespecíficas, sobressaem-se o predatismo (predador versus presa) e o parasitismo. Entre as relações desarmônicas intraespecíficas, poderíamos trazer à baila a competição, que se dá também nas interespecíficas. Aquilo que se chama 'comunhão' (pressuposto para interação comunicativa) se enquadra nas relações harmônicas intraespecíficas. Enfim, na própria ecologia geral temos conceitos para efetuarmos estudos críticos sobre diversos assuntos. Nos dias atuais não precisamos mais ter medo do biologismo. Usar a ecologia geral como base para os estudos culturais (e linguísticos) é assumir o ponto de vista da vida, justamente estudada pela biologia, de que a ecologia geral (e a linguística) faz parte.

$\mathrm{Na}$ linguística ecossistêmica, não precisamos recorrer a nenhuma ideologia extraecológica (religiosa, marxista, política, partidária etc.). A ecolinguística em geral já encontra, na própria fonte de que emana, tudo de que precisa para erigir seu arcabouço epistemológico, assim como todos os recursos heurísticos para se analisar criticamente todo e qualquer fenômeno linguístico. No caso do estudo de textos (anti)ambientalistas, essa postura implica a assunção de uma ideologia ecológica, ou ideologia da vida, que, como disse o filósofo norueguês da ecologia profunda Arne Naess, não é apenas descritiva, mas também prescritiva e crítica. Ela luta pelos seres vivos de todas as espécies, criticando quem vai contra a defesa da vida na face da terra. Aí temos um ramo da linguística ecossistêmica que poderia ser chamado de linguística ecossistêmica crítica (LEC), que se distinguiria da 'ecolinguística crítica' justamente por sua postura intervencionista em prol da vida (não política, não religiosa e apartidária) e por partir do conceito central da ecologia, o ecossistema. Seu ponto de honra é a vida, sob todas as suas formas. Um nome alternativo, na verdade o mais usado, para essa vertente da linguística ecossistêmica é análise do discurso ecológica (ADE). 


\section{Comunhão}

Um aspecto de fundamental importância não só para a ecolinguística em geral, mas também para a linguística ecossistêmica, é a comunhão. Por isso, gostaria de discuti-la com um pouco mais de detalhe. O conceito foi originalmente proposto por Malinowski (1972) como "comunhão fática". Em seguida, ele foi retomado por Roman Jakobson, no contexto de suas funções da linguagem. O linguista francês Gobard (1976) foi talvez o terceiro linguista a tocar no assunto. Sob as denominações de 'simbiose' e 'fraternization' (do francês 'fraternisation'), William Samarin também discute algo semelhante.

Para Gobard, "a condição sine qua non de todo desenvolvimento humano é a relação afetiva em que a linguagem serve de suporte a uma comunhão e não a uma comunicação" (p. 23). Continua afirmando que "a criança, em presença de sua mãe, que diz 'mamãe' não comunica nada, mas apenas comunga toda sua relação" (p. 27). O autor acrescenta que "o espírito de comunhão [...] está necessariamente ligado a uma comunidade de dimensão pequena" (p. 28). Por fim, para ele "cada grupo natural secreta assim sua própria linguagem de comunhão, para a qual o que importa não é propriamente comunicar, uma vez que todos os membros do grupo sabem as mesmas coisas, mas confirmar o que já se sabia" (p. 28).

Como já mostrei, sobretudo em Couto (2001, 2009), comunhão é uma espécie de solidariedade que mantém a coesão de um grupo social, de qualquer tamanho que ele seja. Se há um grupo de pessoas juntas, a comunhão é aquele estado de espírito que consiste na consciência de estarem em sintonia, em harmonia. Mesmo que ninguém diga nada a outrem, estão todos prontos para ouvir seja lá o que for que alguém venha a dizer. É uma espécie de predisposição para a comunicação propriamente dita. Nos termos de Jakobson, que estava falando em "função fática" da linguagem, ela consiste em abrir o canal de comunicação (alô, bom dia, oi), mantê-lo aberto (tá, hum-hum, cê tá me ouvindo?) e fechá-lo (tchau) e assim por diante (Jakobson, 1969). 
No contexto da linguística ecossistêmica, a comunhão pode ser encarada da perspectiva da ecologia da interação comunicativa, em que é uma espécie de traço de união entre falante e ouvinte. Eles têm que entrar em comunhão antes que qualquer comunicação eficaz seja possível. Mesmo que se trate de alguém em uma cidade estranha, que precise de uma informação de algum transeunte, é necessário que o falante se dirija ao estranho com algo como por favor! Com isso, o estranho certamente parará e se voltará para ele. A partir desse momento, o falante poderá perguntar, por exemplo, "onde fica a rua Tiradentes?". Se souber onde ela fica, o transeunte com certeza dará a informação solicitada. Se não souber, se desculpará e sugerirá que ele pergunte a outra pessoa. $\mathrm{O}$ fato é que sem comunhão não há comunicação. Mesmo que seja uma microcomunhão.

Em um nível maior também pode, e deve, haver comunhão. Na verdade, é ele que mantém coeso o grupo de pessoas que constituem o bioma linguístico (ecossistema linguístico geral, comunidade de língua). Portugal, Brasil, Angola, Moçambique, Cabo Verde, Guiné-Bissau, São Tomé e Príncipe e Timor Leste constituem a comunidade de língua portuguesa, o domínio da língua portuguesa, porque quem vive nesses países sabe que o modo costumeiro de se comunicar é pelo que se tem chamado de 'língua portuguesa'. Por isso estão de certa forma em sintonia, têm laços de solidariedade que são a cultura (C) e a língua comuns. É, como se vê, o domínio do sistema dessa língua. Trata-se de uma espécie de contrato tácito. Esse compartilhamento de um sistema linguístico é um caso de macrocomunhão. $\mathrm{O}$ conceito mereceria uma discussão muito mais detalhada, mas, como não é possível fazê-lo aqui, remeto o(a) leitor(a) aos textos acima referidos. Em Couto (2001) e Couto (2013) há uma discussão mais atualizada sobre o assunto.

\section{Ecologia da interação comunicativa}

Sabemos que o traço definidor do ecossistema são as interações, tanto (a) as interações organismo-mundo quanto (b) a interações organismo-organismo. Vimos que na ecologia linguística 
as primeiras são as relações de significação, designação, referência etc. e as segundas são as interações comunicativas. Na verdade, as duas estão intimamente associadas, uma vez que nós (organismos humanos) interagimos uns com os outros para comunicarmos sobre o meio (natural, mental, social). Por outro lado, nossas relações com o mundo ou meio ambiente (circundante) só serão consideradas linguísticas se passarem pela mente e forem sancionadas pela coletividade, a sociedade. Enfim, tudo na língua começa nos atos de interação comunicativa, que ocorrem no contexto da ecologia da interação comunicativa (EIC). Trata-se de um fluxo interlocucional, um diálogo, entre falante (EU) e ouvinte (TU), sendo que há uma alternância entre eles: quem era falante num primeiro momento, passa a ser ouvinte num segundo; quem era ouvinte num primeiro momento, passa a ser falante em um segundo, e assim sucessivamente, como se pode ver detalhadamente em Couto (2013). Como esse fluxo está exposto nesse livro em pormenores, aqui vou examinar outros aspectos da ecologia da interação comunicativa.

Tradicionalmente, tínhamos o famoso 'circuito da fala' de Saussure e o 'modelo de comunicação' dos engenheiros da comunicação. Como ambos são fechados e estáticos, a linguística ecossistêmica vem desenvolvendo um modelo mais ágil, aberto e dinâmico, como é qualquer diálogo. Assumindo a postura onomasiológica (que parte do conceito), notamos que o núcleo duro de qualquer ato de interação comunicativa é constituído por EU e TU. O EU vem acompanhado daquele ou daqueles que vivem, convivem e/ou estão com ele, os seus, o $E_{\text {a }}$. O TU também vem com aquele ou aqueles que estão do seu lado nas mesmas condições, $\mathrm{ELE}_{\mathrm{b}}$. Combinando essas quatro realidades, que emergem naturalmente do esquema da comunicação dos engenheiros da comunicação, temos todos os demais componentes, reais ou virtuais, da EIC. Vejamos todos eles (inclusivo/exclusivo $=$ inclui/exclui o ouvinte).

1) $\mathrm{EU}+\mathrm{ELE}_{\mathrm{a}}=\mathrm{NÓS}_{1}$ (inclusivo)

2) $\mathrm{EU}+\mathrm{TU}=\mathrm{NÓS}_{2}$ (exclusivo)

3) $\mathrm{EU}+\mathrm{ELE}_{\mathrm{a}}+\mathrm{TU}=\mathrm{NÓS}_{3}$ (inclusivo)

4) $\mathrm{EU}+\mathrm{TU}+\mathrm{ELE}_{\mathrm{b}}=\mathrm{NÓS}_{4}$ (inclusivo) 
5) $\mathrm{EU}+\mathrm{ELE}_{\mathrm{a}}+\mathrm{ELE}_{\mathrm{b}}=\mathrm{NÓS}_{5}$ (exclusivo)

6) $\mathrm{EU}+\mathrm{ELE}_{\mathrm{b}}=\mathrm{NÓS}_{6}$ (exclusivo)

7) $\mathrm{EU}+\mathrm{ELE}_{\mathrm{a}}+\mathrm{TU}+\mathrm{ELE}_{\mathrm{b}}=\mathrm{NÓS}_{7}$ (inclusivo)

8) $\mathrm{TU}+\mathrm{ELE}_{\mathrm{b}}=$ VÓS $_{1}$ (exclusivo: não inclui quem está com EU)

9) $\mathrm{TU}+\mathrm{ELE}_{\mathrm{a}}+\mathrm{ELE}_{\mathrm{b}}=$ VÓS$_{2}$ (inclusivo: inclui quem está com EU)

10) $\mathrm{TU}+\mathrm{ELE}_{\mathrm{a}}=\mathrm{VÓS}_{3}$ (inclusivo: inclui quem está com EU)

11) $\mathrm{ELE}_{\mathrm{a}}+\mathrm{ELE}_{\mathrm{b}}=$ ELES (todos, tudo)

ELE $_{\text {a }}$ seria bem mais apropriadamente representado como ELE $_{\mathrm{a} 1,2,3, \ldots, \mathrm{n}}$, a fim de mostrar que os que estão do lado de EU são em número aberto. Trata-se de todo mundo que de alguma forma está relacionado com ele. $\mathrm{O}$ mesmo vale para $\mathrm{ELE}_{\mathrm{b}}$, que, na verdade, deve ser representado como $\mathrm{ELE}_{\mathrm{b} 1,2,3, \ldots, n}$, pois inclui todos os que estão relacionados a TU. Poder-se-ia dizer que se trata das duas metades da comunidade, ou seja, tudo que está do lado do falante e do ouvinte, respectivamente. ELE $_{a}$ e ELE ${ }_{b}$, juntos, formam ELES.

Nem todos esses conceitos virtuais são representados na realidade das línguas do mundo. Em português usamos apenas 'eu', 'tu', 'ele', 'nós', 'vós' e 'eles' (e variantes) para todo e qualquer um desses conceitos. No entanto, algumas línguas lexicalizam outras possibilidades. O tupi e o guarani lexicalizam a possibilidade (1) como oré (nós exclusivo) e a (2) como jandé (nós inclusivo). No crioulo inglês da Papua-Nova Guiné, conhecido como tok pisin, há outras possibilidades, entre elas as seguintes:

1) $\mathrm{NÓS}_{1}=$ mitupela (exclusivo)

2) $\mathrm{NÓS}_{2}=$ yumitupela (inclusivo)

4) $\mathrm{NÓS}_{4}=$ yumitripela (inclusivo)

5) $\mathrm{NÓS}_{5}=$ mitripela (exclusivo)

6) $\mathrm{NÓS}_{6}=$ mitupela (exclusivo)

7) $\mathrm{NÓS}_{7}$ = yumi ou yumipela (inclusivo)

8) VÓS, yutupela (exclusivo: não inclui quem está com EU)

9) VÓS yutripela (inclusivo: inclui quem está com EU)

10) VÓS ${ }_{3}$ yutupela (inclusivo: inclui quem está com EU) 
Para a "terceira pessoa", a forma básica é em $(<h i m)$. O plural é tupela e três é tripela, ou seja, a língua tem uma forma trial. Seria interessante um estudo comparativo que mostre como cada língua codifica esses conceitos e porquê. Voltando às formas possíveis de (1) a (11) acima, podemos entender melhor porque os atos de interação comunicativa são a base da língua. É que eles são parte da ecologia da interação comunicativa, que é parte do ecossistema ecolinguístico local, conhecido como comunidade de interação (comunidade de fala). Os conceitos de $\operatorname{ELE}_{\mathrm{a} 1,2,3, \ldots, \mathrm{n}, \mathrm{por}}$ um lado, e $\mathrm{ELE}_{\mathrm{b} 1,2,3, \ldots, \mathrm{n}}$, por outro lado, remetem para 'as mil coisas' do mundo segundo a filosofia chinesa, vale dizer, a tudo de que EU pode falar para TU. Ele pode falar inclusive de si mesmo (me, mim, migo) e do próprio TU (te, ti, tigo). O 'nós' do número (7), ou seja, $\mathrm{NÓS}_{7}$, é abrangente. Ele representa a comunidade inteira. Se incluir 'os que estão com EU' e 'os que estão com TU' do espaço imediatamente circunjacente, temos o ecossistema linguístico local ou comunidade de fala (comunidade de interação), como já visto. Mas, se incluir todos os componentes de ELE $_{\mathrm{a} 1,2,3, \ldots, \mathrm{n}}$ e de $\mathrm{ELE}_{\mathrm{b} 1,2,3, \ldots, \mathrm{n}}$, ou seja, acrescentando os imediatos e os mediatos como um todo, temos o ecossistema linguístico geral, o bioma linguístico ou a comunidade de língua (comunidade de sistema). O ELES pode se referir pelo menos a duas coisas diferentes. No contexto das comunidades de interação e de sistema, ele se refere à totalidade de P. No caso dos contatos interlinguísticos e interculturais, pode contrapor-se ao 'nós', os da nossa comunidade. Em suma, da EIC emerge a língua como um todo.

O 'nós' comunidade de interação pode ser de tamanhos os mais variados, indo desde o grupo de alunos de uma sala de aula até um país inteiro (ou mais). No geral, ele é de pequenas proporções, como vimos com Gobard. O fato é que a ecologia da interação comunicativa começa pelos atos de interação comunicativa, a comunicação, mas se estende também até a comunidade de língua. Na verdade, tudo é comunidade de fala, pequena ou grande. O núcleo da EIC, ou seja, EU mais TU, formam a comunidade fala mínima. A totalidade das regiões em que a língua em questão é falada constitui a comunidade de fala máxima, equivalente da comunidade de língua. 
De modo que podemos concluir afirmando que tudo na ecolinguística, mais ainda na linguística ecossistêmica, começa e termina nos atos de interação comunicativa, na ecologia da interação comunicativa. É das inter-relações entre comunidade de interação e comunidade de sistema que se constitui o que se chama língua.

É interessante lembrar que a expressão 'comunidade de interação' é de origem alemã, sob a forma de Interaktionsgemsinschaft, que aparece também como Kommunikationsgemeinschaft (comunidade de comunicação). O fato de 'comunicação' ter o mesmo radical que 'comunidade' e 'comunhão' não é gratuito. Na verdade, 'comunidade' é o agrupamento de pessoas que se sentem juntas pela força de coesão da comunhão, que leva à comunicabilidade, à possibilidade de comunicação.

É importante lembrar que o núcleo da EIC é o diálogo, uma sequência de tomadas de turno que segue dois tipos de regras, quais sejam, as (a) regras sistêmicas e as (b) regras interacionais, brevemente discutidas em Couto (2013). Em geral se diz que toda regra tem exceção. No caso, toda regra é infringível, dependendo das condições da ecologia da interação comunicativa, pois, como no ditado italiano, fatta la legge trovato l'inganno (feita a lei, encontrada a burla).

\section{Considerações finais e perspectivas}

Tudo que começa com "eco-" é encarado de soslaio pela academia, e os ecolinguistas e outros estudiosos de ecociências estão conscientes do fato. A despeito disso, há um leque de possibilidades de pesquisa incalculável no âmbito da ecolinguística, como mostrou Peter Finke. É uma possibilidade única de se fazer algo inteiramente novo nos estudos da linguagem, e não ficar repetindo versões diferentes de teorias lógico-positivistas, embora a segunda postura possa trazer muitas vantagens práticas, como financiamentos de pesquisa. $\mathrm{O}$ proponente da hipótese de Gaia, James Lovelock, já havia dito que "os cientistas [...] imersos na redução de uma única página, não estão interessados no livro, nem mesmo num capítulo. Ideias abrangentes, como Gaia, 
são um anátema para eles. Veem Gaia como [...] algo próximo da fé religiosa, [...] por isso, [...] algo a ser rejeitado" (Lovelock, 2001: 13). Enfim, a academia não gosta muito de novidades.

Quem assume a postura ecológica, quem é adepto da ecologia (não só a ambientalista), como fazem os praticantes de linguística ecossistêmica e seus predecessores, está consciente de que cada especialista pode até continuar em sua área, mas sem esquecer que ela é parte de um todo maior. Por exemplo, há ecolinguistas que provieram da crioulística (como Peter Mühlhäusler), muitos começaram como praticantes de linguística aplicada (como o próprio Alwin Fill), outros vieram da análise do discurso (como Richard Alexander). Existem os que eram originalmente praticantes de endoecologia linguística, mais especificamente morfossintaxe e lexicologia (como Adam Makkai). Eu mesmo era, originalmente, fonólogo e continuo dando aulas de fonologia esporadicamente. Já disse acima que em minha última publicação na área tentei mostrar que alguns fenômenos da dinâmica acentual dos proparoxítonos em português tem a ver com a memória que os falantes têm de fenômenos que já não se manifestam foneticamente. É como os genes recessivos que, mesmo não se manifestando no filho, podem emergir de novo no neto ou até no bisneto (Couto, 2008).

Enfim, o linguista não precisa abandonar o que já vinha fazendo para se tornar um bom ecolinguista. Se ele é um bom especialista, tornar-se-á melhor ainda se inserir sua especialidade em um contexto maior, em uma concepção de mundo que esteja em sintonia com a ciência moderna, que tenha rompido com a ciência mecanicista de Newton e o positivismo em ciências sociais. Vimos acima com Capra que a ecologia é um exemplo de contexto maior. O que é mais, é um contexto maior que parte da ciência da vida, uma vez que ecologia é parte da biologia, a ciência da vida. Numa época de crescente degradação de nosso entorno vital, isso adquire ainda mais sentido.

Recebido: 04/09/2012

Aceito: $27 / 11 / 2012$

hiho@unb.br ou hildodocouto@gmail.com ou

hildo@phu.org.br 


\section{Referências bibliográficas}

ALMEIDA, C. A. F. de. A comunicação entre os membros de uma comunidade de surdos (cegos) de Prata (MG). Dissertação de Mestrado, UnB, 2004.

A aquisição da linguagem por uma surdocega pré-linguística numa perspectiva sociocognitiva. Tese de doutorado, UnB, 2008.

BOFF, L. As quatro ecologias: ambiental, política e social e integral. Rio de Janeiro: Mar de Ideias, 2012. Há uma síntese em http://www.leonardoboff. com.br (acesso: novembro 2012).

CAPRA, F. O tao da física. São Paulo: Cultrix, 2002.

COUTO, E. K. N. N do. Ecolinguística e imaginário. Brasília: Thesaurus, 2012. (SP): Pontes, 2013.

Ecolinguística: Um diálogo com Hildo Honório do Couto. Campinas COUTO, H. H. do. Semiótica da cultura e tradução. In: Matos, Delton (org.). Estudos de tradutologia I. Brasília: Kontakt, 1981, p. 9-32.

. Linguística e semiótica relacional. Brasília: Thesaurus, 1982.

. A interação entre portugueses e ameríndios em Porto Seguro em 1500. Pesquisa linguística (PPGL-UnB), n. 6, vol. 2, p. 7-28, 2001 (UnB).

. Ecolinguística: estudo das relações entre língua e meio ambiente. Brasília: Thesaurus, 2007.

. Algumas restrições aos proparoxítonos em português. In: Roncarati, Cláudia e Juçara Abraçado (orgs). Português brasileiro II: contato linguístico, heterogeneidade e história. Niterói, EDUFF/FAPERJ, pp. 118-136, 2008.

. Linguística, ecologia e ecolinguística: contato de línguas. São Paulo: Contexto, 2009.

"Linguística ecossistêmica", 2012, disponível em http:// meioambienteelinguagem.blogspot.com.br/2012/06/linguisticaecossistemica.html (21/09/2012).

. “Análise do discurso ecológica”, 2013, disponível em (02/04/2013).

http://meioambienteelinguagem.blogspot.com.br/2013/04/analise-dodiscurso-ecologica.html

DÖRING, M; H. PENZ; W. TRAMPE (orgs.). Language, signs and nature: ecolinguistic dimentions of environmental discourse. Tübingen: Stauffenburg, 2008. 
FERREIRA, A. C. Algumas "colorless (?) green ideas": Uma introdução à ecolinguística. Estudos de linguística contrastiva e interdisciplinar (alemãoportuguês). Cadernos do CIEG n. 10, p. 25-46, 2003.

FILL, A. Ökologie: Eine Einführung. Tübingen: Gunter Narr Verlag, 1993. 1996. (org.). Sprachökologie und Ökolinguistik. Tübingen: Stauffenburg,

; H. PENZ (org.). Sustaining language: Essays in Applied Ecolinguistics. Viena/Berlim: Lit Verlag, 2007.

; H. PENZ; W. TRAMPE (orgs.). Colourful green ideas. Berma/ Berlim: Peter Lang, 2002.

FILL, A.; P. MÜHLHÄUSLER (orgs.). The ecolinguistics reader. Londres: Continuum, 2001.

GOBARD, H. L'Aliénation linguistique: analyse tetraglossique. Paris: Flammarion, 1976.

GARNER, M. Language: An ecological view. Oxford/Berlim: Peter Lang, 2004.

GUATTARI, F. As três ecologias. São Paulo: Papirus, 2011, $21^{\text {a }}$ ed., 2011.

GÜNTHER, H. ; REINIER J. A. Rosestraten. Psicologia ambiental : considerações sobre sua área de pesquisa. Série Textos de Psicologia Ambiental n. 10, Laboratório de Psicologia Ambiental, UnB, 2005.

HAGÈGE, C. L'homme de paroles. Fayard, Paris, 1985.

HARRÉ, R.; J. BROCKMEIER; P. MÜHLHÄUSLER. Greenspeak: A study of environmental discourse. Thousand Oaks, Cal.: Sage Publications, 1998.

HAUGEN, E. The ecology of language. The ecology of language. Stanford: Stanford University Press: 325-339, 1972 (também em Fill; Mühlhäusler, pp. 57-66, 2001).

JAKOBSON, R. Linguística e poética. Linguagem e comunicação. São Paulo: Cultrix, 1969 (original de 1960).

KETTEMANN, B.; H. PENZ (orgs.). ECOnstructing language, nature and society. Tübingen: Stauffenburg, 2000.

KRAMSCH, C (org.). Language acquisition and language socialization: Ecological perspectives. Londres: Continuum, 2002.

LAMB, S. M. Neuro-cognitive structure in the interplay of language and thought. In: Pütz, Martin; Marjolijn H. Vespoor (orgs.) Explorations in linguistic relativity. Amsterdam: Benjamins, pp. 173-196, 2000.

LEATHER, J.; J. van DAM (orgs.). Ecology of language acquisition. Dordrecht: Kluwer Academic Publishers, 2003. 
LÉVI-STRAUSS, Claude. 1970. Antropologia estrutural. Rio de Janeiro: Tempo Brasileiro, $3^{\mathrm{a}}$. ed.

LOVELOCK, J. Gaia: Um novo olhar sobre a vida na terra. Lisboa: Edições 70, 2001.

MAFFI, L. On biological diversity: Linking language, knowledge and the environment. Washington: Smithsonian Institution Press, 2001.

MAKKAI, A. Ecolinguistics: ¿Toward a new ${ }^{* *}$ paradigm ${ }^{* *}$ for the science of language? Londres: Pinter Publishers, 1993.

MALINOWSKI, B. O problema do significado em linguagens primitivas. In: OGDEN, C. K.; RICHARDS, I. A. O significado de significado. Rio de Janeiro: Zahar Editores, p. 295-330, 1972.

MELO, J. D. de. O calon dos ciganos do nordeste de Goiás: uma língua obsolescente. Dissertação de mestrado, UnB, 2005, publicada como o livro Os ciganos calon de Mambaí: A sobrevivência de sua língua (Brasília: Thesaurus, 2005).

A língua da comunidade calon da região norte-nordeste do estado de Goiás. Tese de doutorado, UnB, 2008.

MUFWENE, S. The ecology of language evolution. Cambridge: Cambridge University Press, 2001.

NEVES, W. Antropologia ecológica. São Paulo: Cortez, 1996.

RAMOS, R. O discurso do ambiente na imprensa e na escola: uma abordagem linguística. Lisboa: Fundação Calouste Gulbenkian \& Fundação Para a Ciência e a Tecnologia, 2009.

SALZINGER, K. Ecolinguistics: A radical behavior theory approach to language behavior. In: AARONSON, D.; REIBER R. W. (orgs.). Psycholinguistics research. Erlbaum, Hillsdale, NJ, p. 109-130, 1979.

SAPIR, E. Language and environment. Selected writings. Berkeley: California University Press, p. 89-103, 1963 (também em Fill; Mühlhäusler, p. 13-23, 2001).

. Língua e ambiente. Linguística como ciência. Rio de Janeiro: Livraria Acadêmica, pp. 43-62, 1969.

SARMENTO, M. S. Ecolexicography - Ecological and unecological words and expressions. In: FILL; PENZ; TRAMPE (orgs.), p. 487-492, 2002.

(s/d). Por uma ecolexicografia.

http://meioambienteelinguagem.blogspot.com.br/2012/02/por-umaecolexicografia.html. 